\title{
West Berlin to be site of new West German AIDS centre
}

\section{Munich}

WEST Berlin will be the site of the new West German AIDS (acquired immune deficiency syndrome) centre, which will open officially next January. The West German Federal Health Office (BGA) says that the centre will serve as a clearinghouse for information about the spread of the disease as well as a research institute.

The new AIDS centre will be housed in the Robert Koch Institute, itself a division of the BGA, but will operate independently. Its main tasks will include collecting data on AIDS epidemiology, standardizing diagnostic tests for HIV (human immunodeficiency virus), managing AIDS research groups already established in West Germany and conducting basic research into both the 'natural history' of the disease and into its psychosocial effects. Perhaps most importantly, the centre will be given the task of assessing AIDS policy in the various Länder(states) and making recommendations to the West German government on how to proceed. The institute is expected to need roughly DM5 million in startup costs in 1988.

West Germany's Research Ministry (BMFT) has spent DM25 million so far on research into the causes and diagnosis of AIDS and is prepared to spend much more next year. The BMFT is placing special emphasis on clinical research into AIDS, apparently to help shore up this traditionally weak area of German research. Pending approval by the Bundestag, the Health Ministry will spend DM135 million on education, counselling and other AIDS-related services, an increase of DM17 million over 1987.

West German health officials have a promising, if unusual, new plan to determine how quickly HIV is spreading to the

\section{Symbolic computer institute in Linz \\ Munich}

The University of Linz in Austria has announced the founding of a new Research Institute for Symbolic Computation (RISC-Linz) with the help of Austria's nationalized steel company VOESTALPINE. The institute, which is also supported by the Austrian and local governments, will investigate all areas of computation that use non-numerical symbols, such as logical formulae and geometric objects. The research at RISC-Linz, which is related to artificial intelligence but has a more industrial bent, will be carried out by a core staff of seven faculty members from Linz University as well as five researchers from industry. population at large. Meinrad Koch of the BGA criticized the suggestion that everyone who is admitted to the hospital should be tested. "Those at risk are seldom in the hospital", he said. Instead, Koch revealed, the $\mathrm{BGA}$ is considering carrying out anonymous tests on the blood of trauma patients - those injured in motorcar or other accidents - in order to see whether AIDS is spreading to the heterosexual population. Heterosexuals are visiting West Berlin AIDS clinics more and more often, said Koch, but few of them are HIV-positive.

The West German Land of Bavaria is the source of continuing conflict over AIDS policy (see Nature 327, 264, 1987). Peter Gauweiler (Christian Social Union,
CSU), state secretary in the Bavarian Interior Ministry, succeeded in introducing a controversial and aggressive AIDStesting plan there in May. The plan calls for "isolation" of some AIDS carriers and for the testing of all immigrants to Bavaria from non-Western European countries.

The CSU is pressing for acceptance of the plan on the federal level. In July, the CSU delegation to the Bundesrat (the upper house of the federal parliament) introduced a bill that demands that West Germany register all AIDS carriers who act in an "unreasonable" way (such as infected prostitutes who do not use condoms) and that the government be empowered to expel foreigners proved to be HIV-positive. Officials like Koch and West German Health Minister Rita Süssmuth oppose the plan, which, said Koch, is "uncalled for, unnecessary and will not in any way inhibit the spread of the disease".
Steven Dickman

\section{US Congress debates legislation in response to AIDS}

\section{Washington}

AIDS (acquired immune deficiency syndrome) was very much on the mind of Congress last week as it wrestled with several pieces of legislation outlining strategies for dealing with the disease.

Congress appears willing to commit large sums of money for programmes to test for HIV (human immunodeficiency virus), the virus causing AIDS, but the debate has focused on whether such tests should be voluntary.

There are some eight different bills before the House of Representatives that address the testing issue. The one that appears to have the broadest support has been introduced by Henry Waxman (Democrat, California), chairman of the health subcommittee of the Energy and Commerce Committee. Identical legislation has been introduced in the Senate.

Waxman's bill would give the Department of Health and Human Services $\$ 400$ million a year for the next three years to establish centres offering voluntary screening for HIV antibodies. The bill requires that testing centres must offer counselling both before and after the test is given and after the results are known. The legislation also lays down strict confidentiality provisions, with fines for violations of privacy. The new act would also prohibit discrimination against those who have evidence of antibodies to HIV.

A stream of public health professionals representing the pillars of the health community - the American Medical Association and the American Nursing Association among others - paraded before Waxman's sub-committee to endorse his legislation.
But sitting to Waxman's left in the committee room was William Dannemeyer (Republican, California), who has different views about how testing should proceed. Dannemeyer has introduced seven separate pieces of legislation that would require mandatory HIV testing for certain segments of the population - couples seeking marriage licences, prostitutes and hospital patients. Dannemeyer also favours disclosing HIV-antibody status of individuals who might infect others, and paraded his own stream of witnesses.

Although voluntary testing and confidentiality are supported by most public health officials, including those in the US Public Health Service, some in the White House lean toward Dannemeyer's view that the civil liberties of a minority of the population may have to be compromised to protect the health of the majority.

The House of Representatives also passed last week a bill authorizing the creation of a National Commission on AIDS. The 15-member commission, appointed by the House, the Senate and the president, would consist of at least eight members from the scientific and medical communities qualified to serve "by reason of education, training or experience". The commission would be charged with advising Congress and the president on policy priorities in research and public health. The House moved with unaccustomed speed to pass the bill creating the commission, in part as a response to criticism of the president's commission announced two weeks ago (see Nature $328,372 ; 1987)$. It is not yet clear when the measure will be brought up in the Senate.

Joseph Palca 